ABDI: Jurnal Pengabdian dan Pemberdayaan Masyarakat ISSN: 2656-369X (Print), 2684-8570 (Online)

Volume 1 No. 1, Juni 2019

http://abdi.ppj.unp.ac.id/index.php/abdi

Email: abdi@ppj.unp.ac.id

DOI: https://doi.org/10.24036/abdi.vlil.6

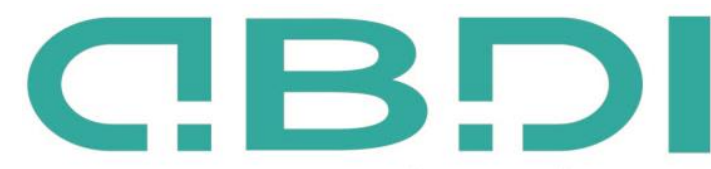

ABDI: JURNAL PENGABDIAN DAN PEMBERDAYAAN MASYARAKAT

\title{
Masyarakat Air Manis Sadar Wisata
}

\author{
Adri Febrianto $^{1}$, Erda Fitriani ${ }^{2}$ \\ 1,2 Jurusan Sosiologi Universitas Negeri Padang \\ Email: febrianto_unp@yahoo.com
}

\begin{abstract}
Abstrak
Artikel ini bertujuan untuk meningkatkan kesadaran wisata masyarakat yang berada di sekitar kawasan wisata Pantai Air Manis, Sumatera Barat. Khalayak sasaran yang strategis dalam kegiatan pengabdian kepada masyarakat ini adalah anggota masyarakat Air Manis khususnya anggota masyarakat yang terlibat langsung dengan aktivitas kepariwisataan, seperti pedagang, tukang parkir, penyedia aktivitas hiburan wisata dan tokoh masyarakat Air Manis. Secara keseluruhan tim mengamati dan menilai bahwa masyarakat mendapat manfaat dari kegiatan ini yaitu meningkatkan kesadaran masyarakat terhadap pariwisata dan menumbuhkan sikap yang sadar wisata serta meningkatkan peran serta masyarakat dalam pembangunan pariwisata. Kegiatan pengabdian berjalan dengan lancar. Salah satu faktornya yaitu tingginya partisipasi masyarakat untuk menghadiri kegiatan ini dan peran aktif dalam kegiatan kepariwisataan.
\end{abstract}

Kata kunci: Pariwisata, Kesadaran wisata, Partisipasi, Ekowisata

\section{Abstract}

This article aims to increase public awareness of tourism around the tourist area of Air Manis Beach, West Sumatra. Strategic target audiences in community service activities are members of the Air Manis community, especially members of the community who are directly involved in tourism activities, such as traders, parking attendants, providers of tourist entertainment activities and leaders of the Air Manis community. Overall the team observed and assessed that the community benefited from this activity, namely increasing public awareness of tourism and fostering a tourism-conscious attitude and increasing community participation in tourism development. Service activities went smoothly. One factor is the high level of community participation in attending this activity and active role in tourism activities.

Keywords: Tourism, Tourism awareness, Participation, Ecotourism

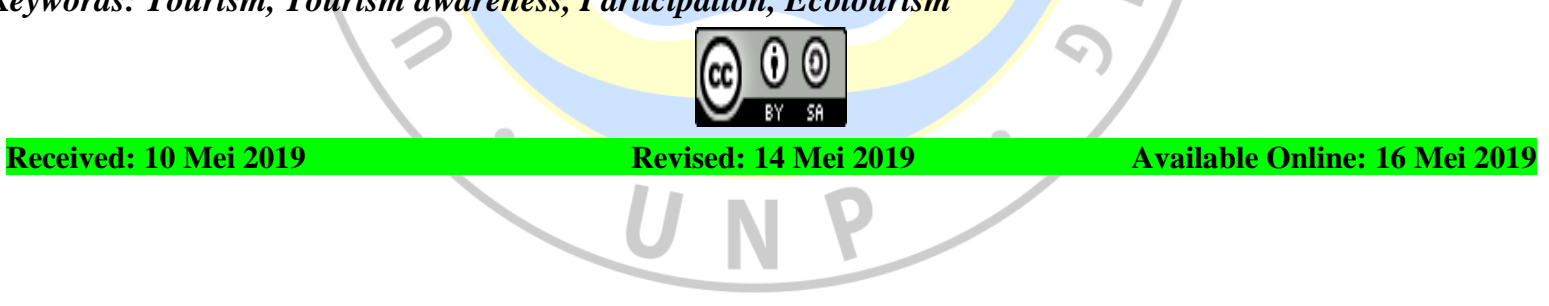




\section{Pendahuluan}

\section{Analisis Situasi}

Sumatera Barat memiliki potensi pariwisata, tidak hanya alam, budaya, akan tetapi juga kekayaan heritage. Angka kunjungan wisatawan ke Sumatera Barat terus mengalami peningkatan. Berdasarkan data dari Dinas Kebudayaan dan Pariwisata Sumbar Pergerakan arus kunjungan wisata ke Sumatera Barat dari tahun ke tahun mengalami kenaikan baik itu wisatawan nusantara maupun wisatawan mancanegara. Dapat dilihat dari tahun 2005-2009, Tahun 2005 jumlah wisatawan nusantara 4.3 juta orang, wisatawan mancanegara sejumlah 84 ribu orang. Pada tahun 2009 jumlah wisatawan nusantara meningkat menjadi 6,7 juta orang dan wisatawan mancanegara berjumlah 151 ribu orang ${ }^{1}$. Ketika terjadi gempa bumi di Sumatera Barat pada 30 September 2009, kota Padang sempat terpuruk karena beberapa hotel mengalami kerusakan dan terjadinya penurunan angka kunjungan wisatawan. Namun setelah pasca gempa Sumatera Barat membangun kembali. Data Badan Pusat Statistik (BPS) menunjukkan sampai Agustus 2013 jumlah wisman yang datang ke Sumbar melalui Bandara Internasional Minangkabau (BIM) dan Pelabuhan Teluk Bayur mencapai 3.466 orang. Jumlah itu naik $44,06 \%$ dibanding periode yang sama tahun lalu, yang tercatat hanya 2.406 orang. Data Disbudpar Sumbar menyebutkan selama tahun 2012, jumlah kunjungan wisman mencapai 36.953 orang, dan meningkat dari tahun sebelumnya yang hanya 33.594 orang. Jumlah itu memang masih sangat jauh dibanding wisatawan nusantara yang jumlahnya mencapai 5.788 .135 orang. ${ }^{2}$

Pariwisata Pantai Air Manis terkenal karena adanya folkore cerita Malin Kundang dan juga keindahan pantai air manis. Daerah ini sudah lama dijadikan daerah tujuan pariwisata. Kalau dibandingkan dengan dua puluh tahun yang lalu maka telah banyak mengalami perkembangan terutama dalam pembenahan sarana dan prasarana. Sarana transportasi untuk menuju ke Pantai Air Manis yaitu angkutan umum dengan trayek angkutan dari kota Padang ke daerah Air Manis. Semenjak dibuatnya jalan oleh pemerintah, kendaran roda empat dapat melewati jalur ini. Selain itu daerah pantai telah ditanami pohon-pohon pinus sebagai peneduh. Pada batu dekat pantai telah dibangun relief yang menceritakan legenda Malin Kundang. Pedagang juga telah dapat ditemui di pantai Air Manis yang menyediakan kebutuhan wisatawan.

Namun walaupun sarana sudah banyak mengalami perubahan, pantai Air Manis sebagai potensi pariwisata belum dikelola secara maksimal. Salah satu yang utama dalam berkembangnya pariwisata secara maksimal yaitu kesadaran masyarakat di sekitar lokasi wisata. Selain itu juga masih kurangnya partisipasi masyarakat dalam pengembangan pariwisata.

Berdasarkan penelitian yang pernah kami lakukan di Pantai Air Manis terlihat bahwa masyarakat lokal memiliki stereotip tertentu terhadap perilaku wisatawan. Masyarakat lokal (host) bereaksi sesuai dengan pola pikir mereka apa yang dilakukan wisatawan di lokasi wisata Pantai Air Manis. ${ }^{3}$ Namun masyarakat belum memberikan pelayanan terhadap wisatawan secara maksimal. Selain itu terdapat perbedaan antara lokasi wisata yang dikelola oleh pemerintah dengan yang dikelola oleh masyarakat sendiri. Pariwisata yang dikelola oleh swadaya masyarakat terlihat kotor, banyak sampah dan pelayanan yang masih kurang terhadap wisatawan. Kondisi ini diasumsikan karena masih kurangnya pemahaman masyarakat terhadap Sadar Wisata. Berdasarkan wawancara dengan masyarakat sekitar lokasi wisata, pemberian sosialisasi oleh Dinas Pariwisata pernah dilakukan satu kali dan belum ada tindak lanjut dari sosialisasi tersebut.

Gejala seperti di atas ternyata merupakan sebuah permasalahan yang perlu menjadi perhatian dari berbagai pihak, terutama UNP Padang. Permasalahan yang hendak diselesaikan di masyarakat sasaran dapat diidentifikasi sebagai berikut: (1) masih adanya sikap masyarakat yang kurang Sadar Wisata; (2) Belum maksimalnya partisipasi masyarakat dalam pembangunan pariwisata; (3) Masih kurang

\footnotetext{
${ }^{1}$ Pergerakan arus kunjungan wisata ke Propinsi Sumatera Barat, data dari Dinas Kebudayaan \& Pariwisata Sumbar, www.sumbarprov.go.id).

${ }^{2}$ http://travelling.bisnis.com/read/20131001/224/166303/banyak-acara-skala-besar-kunjungan-turis-ke-sumbar-meningkat ${ }^{3}$ Fitriani, Erda \& Adri Febrianto. Stereotipe Masyarakat Lokal terhadap Perilaku Wisatawan, Laporan penelitian dana DIPA tahun 2014. UNP.Padang.
} 
penyebaran informasi tentang Sadar Wisata. Kondisi ini menjadi landasan untuk melakukan pengabdian masyarakat guna untuk melakukan penyuluhan dan pelatihan Sadar Wisata bagi masyarakat di kawasan pantai Air Manis dalam meningkatkan partisipasi masyarakat dalam pembangunan pariwisata.

\section{Perumusan Masalah}

Berdasarkan latar belakang di atas, maka yang menjadi permasalah dalam kegiatan ini yaitu pariwisata mengalami peningkatan di Sumatera Barat, khususnya di lokasi wisata Pantai Air Manis, namun peran serta masyarakat dan perilaku masyarakat sekitar lokasi wisata Pantai Air Manis (Host), masih belum maksimal dalam melayani wisatawan. Dengan demikian yang akan menjadi permasalahan yang hendak diselesaikan dalam pengabdian masyarakat ini yaitu bagaimana memberikan kesadaran kepada masyarakat di kawasan wisata pantai Air Manis akan arti penting pariwisata terutama dalam meningkatkan partisipasi masyarakat dalam pembangunan pariwisata di pantai Air Manis?Permasalahan tersebut dapat dibatasi sebagai faktor kurangnya pengetahuan masyarakat akan pentingnya pariwisata (sadar wisata)

\section{Tujuan Kegiatan}

Kegiatan ini bertujuan untuk: menumbuhkan kesadaran masyarakat terhadap pariwisata, memberdayakan masyarakat dan mengembangkan potensi pariwisata pantai Air Manis dalam meningkatkan kesejahteraan masyarakat, dan meningkatkan peran serta masyarakat dalam pembangunan pariwisata.

\section{Manfaat Kegiatan}

Manfaat kegiatan ini diharapkan dapat meningkatkan kesadaran masyarakat terhadap pariwisata dan menumbuhkan sikap yang sadar wisata serta meningkatkan peran serta masyarakat dalam pembangunan pariwisata.

\section{Metode Pelaksanaan}

Berdasarkan analisis situasi, rumusan masalah, dan tujuan kegiatan maka kerangka pemecahan masalah tersebut adalah:

\section{Tabel 1. Metode Pelaksanaan Pengabdian Masyarakat}

\begin{tabular}{|c|c|c|}
\hline Masalah & Pemecahan & Hasil \\
\hline $\begin{array}{l}\text { 1.Kurangnya pemahaman } \\
\text { tentang pariwisata }\end{array}$ & $\begin{array}{l}\text { 1. Memberikan } \\
\text { informasi atau } \\
\text { pengetahuan tentang } \\
\text { pariwisata dan sadar } \\
\text { wisata }\end{array}$ & $\begin{array}{l}\text { 1. Memiliki pengetahuan } \\
\text { tentang pariwisata } \\
\text { dan sadar wisata }\end{array}$ \\
\hline $\begin{array}{l}\text { 2. Kurangnya perilaku } \\
\text { masyarakat dalam } \\
\text { melayani wisatwan }\end{array}$ & $\begin{array}{l}\text { 2. Memberikan } \\
\text { pelatihan } \\
\text { kepariwisataan }\end{array}$ & $\begin{array}{l}\text { 2. Memiliki sikap sadar } \\
\text { wisata dan sapta } \\
\text { pesona }\end{array}$ \\
\hline $\begin{array}{l}\text { 3.Kurangnya partisipasi } \\
\text { masyarakat dalam } \\
\text { pembangunan } \\
\text { pariwisata }\end{array}$ & $\begin{array}{l}\text { 3. Memberikan motivasi } \\
\text { dan pengetahuan } \\
\text { tentang peran serta } \\
\text { masyarakat }\end{array}$ & $\begin{array}{l}\text { 3. Meningkatnya } \\
\text { partisipasi masyarakat } \\
\text { dalam pembangunan } \\
\text { pariwisata }\end{array}$ \\
\hline
\end{tabular}

\section{Realisasi Pemecahan Masalah}

Dalam merealisasikan pemecahan masalah, maka dilakukan kegiatan "Penyuluhan dan Pelatihan Sadar Wisata Bagi Masyarakat". Kegiatan ini dilakukan dengan melibatkan 4 (empat) orang narasumber yang disesuaikan dengan bidang keahlian mereka masing-masing. Narasumber berasal dari Dinas Pariwisata, dan peneliti bidang pariwisata.

$$
\begin{array}{r}
\text { ABDI: Jurnal Pengabdian dan Pemberdayaan Masyarakat Vol. } 1 \text { No. } 1 \\
\text { E-ISSN: 2684-8570| ABDI } 2019 \\
\text { Copyright }{ }^{\odot} 2019 \text {, By Author }
\end{array}
$$




\title{
Khalayak Sasaran
}

Khalayak sasaran dalam pengabdian masyarakat ini yaitu masyarakat yang berada di kawasan wisata pantai Air Manis. Jumlah peserta 65 orang, laki-laki dan perempuan serta dari berbagai kalangan masyarakat di Kelurahan Air Manis seperti tokoh masyarakat, pedagang, pegawai kantor lurah Air Manis, serta pegawai pariwisata di Air Manis. Sebagai khalayak sasaran sangat strategis karena anggota masyarakat terutama yang berinteraksi langsung dengan wisatawan merupakan aktor yang memiliki peran sangat penting dalam pengembangan pariwisata pantai Air Manis.

\section{Metode Penerapan}

Metode penerapan dengan melakukan berbagai kegiatan pada masyarakat di kawasan wisata pantai Air Manis dengan melakukan aktivitas yaitu:

(1) Kegiatan pengabdian kepada masyarakat ini dilaksanakan melalui penyuluhan dan diskusi. Dalam pelaksanaan, diharapkan terjadi komunikasi dua arah, baik antara narasumber dengan peserta maupun antara sesama peserta sendiri, sekaligus meningkannya pemahaman masyarakat mengenai pariwisata.

(2) Materi pelatihan meliputi:

a. Kesiapan masyarakat lokasi wisata

b. Sadar wisata

c. Sapta Pesona

d. Pembangunan Wisata berkelanjutan

e. Partisipasi masyarakat dalam pembangunan pariwisata

\section{Evaluasi Pelaksanaan Kegiatan}

Evaluasi pelaksanaan kegiatan dapat dianalisis dari aspek kognitif dan afektif peserta pelatihan. Aspek kognitif dapat diketahui dari peningkatan pengetahuan masyarakat Air Manis mengenai sadar wisata dan sapta pesona. Sedangkan aspek afektif dapat diketahui dari perubahan sikap masyarakat sekitar kawasan wisata panatai Air Manis dalam melayani wisatawan baik wisatawan domestik maupun wisatawan asing. Selanjutnya diharapkan adanya peningkatan partisipasi masyarakat di dalam pembangunan pariwisata pantai Air Manis.

\section{Pembahasan}

\section{Analisis Evaluasi Pelaksanaan Kegiatan}

Kegiatan penyuluhan dilaksanakan dalam dua tahapan. Kegiatan bertujuan untuk meningkatkan pengetahuan para peserta mengenai Pariwisata, Sapta Pesona serta menciptakan kesadaran wisata masyarakat Air Manis.

\section{Tahap I}

Tahap pertama ini merupakan kegiatan seminar dalam rangka untuk memberikan pengetahuan atau sosialisasi kepada masyarakat Air Manis mengenai Sadar Wisata dan Sapta Pesona. Jumlah peserta yaitu 65 orang. Kegiatan dilakukan pada:

\author{
Hari/Tanggal $:$ Rabu/ 28 Oktober 2015 \\ Waktu : $09.00 \mathrm{~s} / \mathrm{d} 16.00 \mathrm{WIB}$ \\ Tempat : Ruang Galeri Pariwisata di lokasi wisata Pantai Air Manis
}

\section{Deskripsi Kegiatan:}

Pada pukul 08.00 WIB tim pengabdian masyarakat sudah sampai di ruang Galeri pariwisata. Ruangan galeri masih kosong, tidak terlihat adanya fasilitas untuk pertemuan di ruangan tersebut. Tidak lama kemudian datang pegawai dinas pariwisata, dan menyatakan bahwa suasana pertemuan di ruangan itu biasanya dilakukan dengan cara duduk lesehan. Dengan demikian, panitia meminta salah seorang untuk menyediakan tikar untuk tempat duduk peserta, tidak lama kemudian tikar sudah tersedia atas bantuan salah seorang penduduk yang tinggal dekat galeri. Panitia menyiapkan ruangan untuk

$$
\begin{array}{r}
\text { ABDI: Jurnal Pengabdian dan Pemberdayaan Masyarakat Vol. } 1 \text { No. } 1 \\
\text { E-ISSN: 2684-8570| ABDI } 2019 \\
\text { Copyright 2019, By Author }
\end{array}
$$


pelaksanaan penyuluhan pariwisata. Satu persatu warga masyarakat mulai berdatangan, tepat pukul 10.00 WIB kegiatan penyuluhan dapat dilaksanakan. Pembukaan acara Penyuluhan dan pelatihan sadar wisata bagi masyarakat kawasan wisata pantai Air Manis dilakukan oleh ketua tim pengabdian masyarakat Bapak Adri Febrianto, S.Sos.,M.Si. sekaligus memberikan kata sambutan dan menyampaikan tujuan dari kegiatan Penyuluhan ini kepada peserta yang hadir. Ketua tim juga memperkenalkan masing-masing anggota tim dan juga dua orang mahasiswa yang ikut membantu pelaksanaan kegiatan.

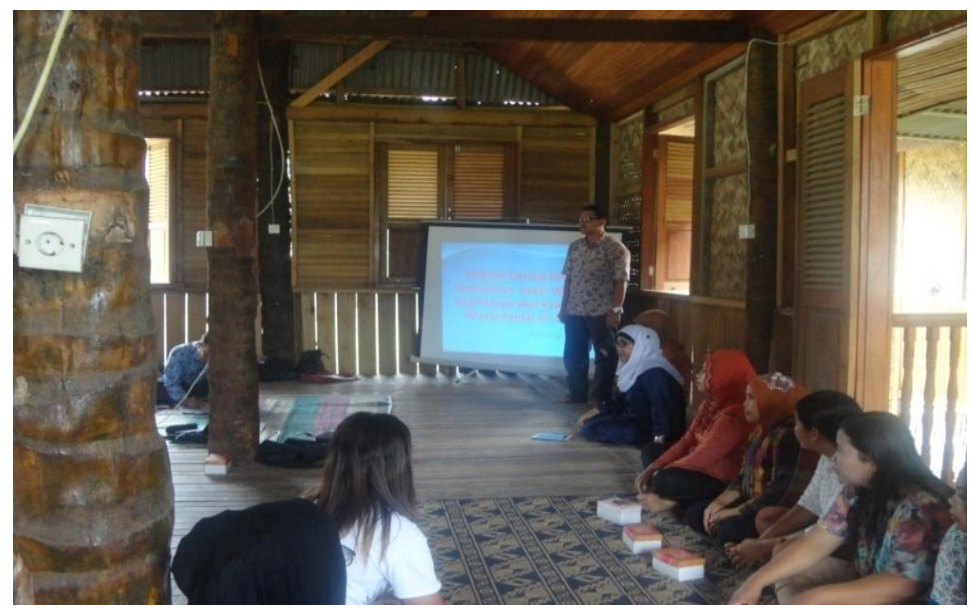

\section{Gambar 1. Pembukaan kegiatan pengabdian masyarakat oleh Adri Febrianto, S.Sos., M.Si}

Kegiatan penyuluhan dan pelatihan Sadar Wisata bagi masyarakat Air Manis dilakukan dalam dua sesi.

\section{Sesi 1}

1. Sesi pertama ini penyampaian materi oleh dua orang narasumber yaitu:

2. Bapak Azwin,SH.,MH adalah pejabat sekretaris Dinas Kebudayaan dan Pariwisata Kota Padang. Bapak Azwin menyampaikan materi dengan tema "Peningkatan Pariwisata Bagi Masyarakat Air Manis".

3. Ibu Dr. Siti Fatimah,M.Pd.,M.Hum. adalah dosen Jurusan Sejarah FIS UNP Padang, dan juga peneliti dan pemberdayaan masyarakat bidang pariwisata khususnya pariwisata Kawasan Mandeh Pesisir Selatan serta perancang Masterplan pariwisata Mandeh. Tema materi yang disampaikan yaitu "Pengembangan Pariwisata Pantai Air Manis Berbasis Masyarakat: pakuak, pakiak, pakak."

4. Moderator dalam kegiatan ini yaitu Erda Fitriani,S.Sos.,M.Si

Narasumber pertama membahas tentang tujuan peningkatan sadar wisata yaitu :

1. Memberikan pemahaman mengenai konsep Sadar Wisata yang akan bermuara pada peningkatan kesejahteraan rakyat;

2. Memberikan acuan bagi segenap pihak dan pemangku kepentingan dalam pengembangan kepariwisataan mengenai pelaksanaan Sadar Wisata;

3. Mendorong peran aktif segenap komponen masyarakat dalam mendukung upaya terwujudnya Sadar Wisata di Pantai Air Manis. 


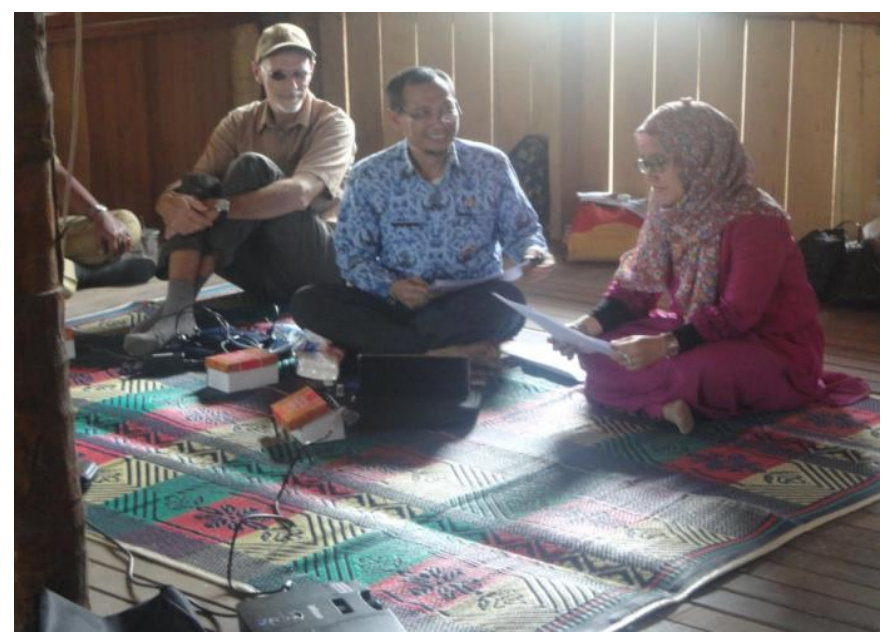

\section{Gambar 2. Penyampaian materi oleh Bapak Azwin, M.H, sekretaris Dinas Pariwisata \& Kebudayaan Kota padang}

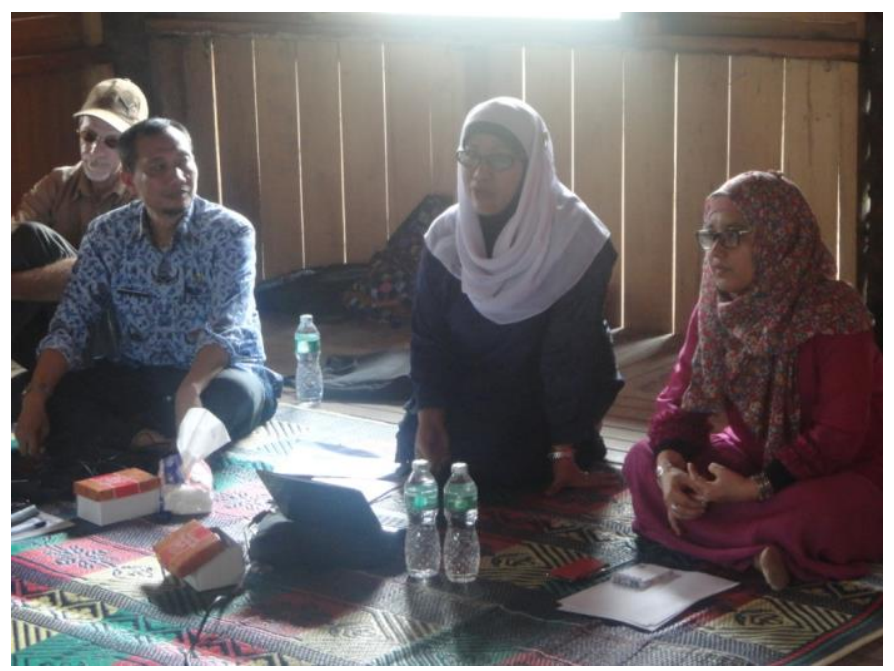

\section{Gambar 3. Narasumber Dr. Siti Fatimah, M.Si.,M.Hum sedang menyampaikan materi}

Harapan dari pariwisata yaitu: Terciptanya suatu kondisi kepariwisataan Indonesia umumnya dan Kota Padang khususnya yang diinginkan (ideal) di tengah-tengah masyarakat melalui penerapan unsur-unsur Sapta Pesona secara konsekuen atas dasar kesadaran yang tumbuh dari dalam diri sendiri

Narasumber kedua membahas mengenai pariwisata Air Manis yang dianalisa sulit dalam pengembangannya. Faktor penyebabnya yaitu penyedian infrastruktur yang belum memada, dan perilaku masyarakat pakuak, pakiak, pakak (kebersihan, kedisiplinan dan kepastian). Menurut narasumber perilaku masyarakat merupakan masalah utama dalam pengembangan pariwisata Air Manis, dan perilaku ini harus diubah ke arah yang lebih baik sesuai dengan Sapta Pesona. Contoh sikap masyarakat yang menghambat pariwisata yaitu :

1. Sikap yang kurang ramah terhadap pengunjung

2. Tidak adanya kepastian (harga minuman, makanan dan cenderamata)

3. Kebersihan lingkungan, tata kelola, manajemen, pemeliharaan flora dan fauna.

Pemberdayaan masyarakat Air Manis dapat dilakukan dalam bentuk :

1. Pembentukan kelembagaan kemitraan dan kelompok sadar wisata. 
2. Pembentukan Badan usaha seperti koperasi wisata, kuliner, pedagang, nelayan dan kelompok lainnya.

3. Pembentukan komunitas atraksi wisata seperti perahu, surfing, hiking, swimming, fishing dan lainlain.

4. Peduli lingkungan (flora, fauna, keamanan pantai dst)

5. Perlu adanya peraturan yang mengatur semuanya diatas.

Sesi pertama ini ditanggapi dengan baik oleh peserta yang pada umumnya adalah pedagang yang ada di lokasi wisata dan juga anggota masyarakat lainnya. Ada tiga orang peserta yang mengajukan pertanyaan kepada narasumber terkait dengan upaya yang harus dilakukan untuk mengembangkan pariwisata pantai Air Manis.

\section{Sesi 2}

Setelah istirahat, makan siang dan sholat pertemuan kembali di buka pukul 13.30 WIB. Para peserta masih antusias, terlihat mereka yang pulang ke rumah kembali lagi ke galeri pariwisata untuk mendengarkan dan mengikuti acara selanjutnya. Narasumber dalam sesi kedua yaitu dua orang yaitu:

1. Bapak Thomas Daniel Huerst, MA adalah dosen luar biasa Jurusan Antropologi di Unand, berasal dari Jerman. Bapak Thomas Daniel menyampaikan materi tentang "Pariwisata Pantai Air Manis suatu Tinjauan".

2. Bapak Adri Febrianto,S.Sos.,M.Si adalah dosen Antropologi di Jurusan Sosiologi FIS UNP, menyampaikan materi "Pariwisata dan Perilaku Masyarakat terhadap Wisatawan."

Narasumber pertama membahas tentang sejarah pariwisata pantai Air Manis, sejak masa Belanda dan masa sekarang. Pariwisata pantai Air Manis pernah mengalami masa dimana banyak turis asing yang datang berkunjung ke pantai Air Manis, dan bahkan juga menginap di homestay yang ada di Air Manis. Namun sekarang ini kondisi pariwisata Air Manis dari sisi pengunjung, didominasi oleh wisatawan domestik, dan datang ke pantai Air Manis dalam jangka waktu singkat. Pengunjung adalah para anak sekolah, remaja (pacaran) dan anggota keluarga.

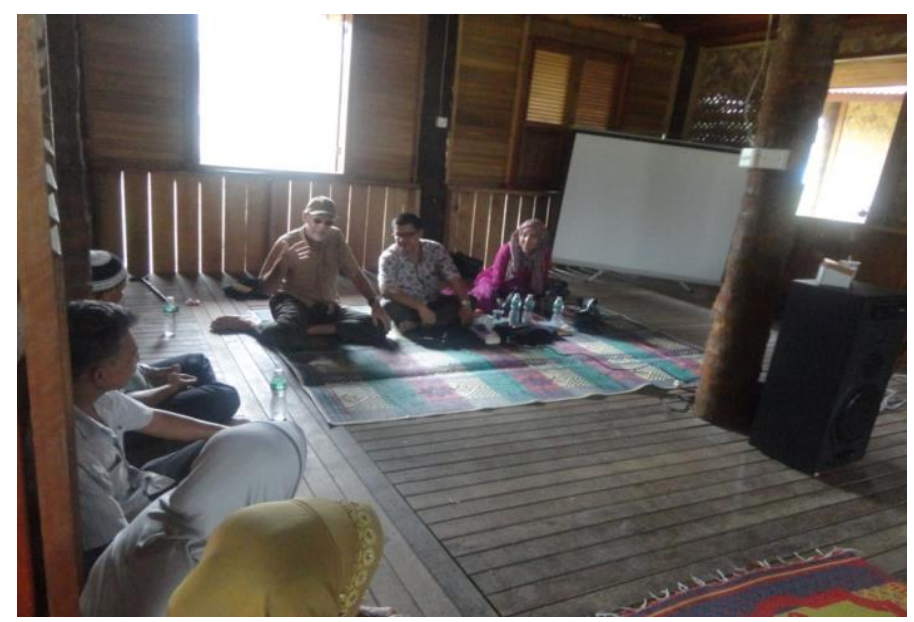

\section{Gambar 4. Narasumber Thomas Danield Huerst, MA sedang menyampaikan materi}

Narasumber kedua membahas tentang perilaku masyarakat tehadap wisatawan. Pantai Air Manis memiliki banyak potensi yang dapat terus dikembangkan, namun aspek perilaku masyarakat dalam melayani wisatawan akan berpengaruh terhadap kunjungan wisatawan ke Air Manis. Wisatawan yang datang merupakan guest atau tamu yang harus dilayani dengan baik, akan tetapi masyarakat diharapkan tidak melupakan sendi-sendi adat dan agama yang ada dalam kebudayaan masyarakat Air Manis. Masyarakat juga mendapatkan dampak dengan adanya pariwisata, seperti dampak ekonomi. Dampak pariwisata yang menguntungkan masyarakat diharapkan terus berkesinambungan atau sustainble bagi 
generasi berikutnya. Dengan demikian masyarakat diharapkan menjadi tradisi dan menjaga lingkungan alam yang ada di lokasi wisata.

\section{Tahap II}

Tahap kedua ini merupakan kegiatan penyuluhan dan pelatihan dalam rangka untuk memberikan pengetahuan atau sosialisasi kepada masyarakat Air Manis mengenai Sadar Wisata dan Sapta Pesona. Kegiatan dilakukan dengan mendatangi warga masyarakat yang dilaksanakan pada:

Hari/Tanggal : Kamis/ 29 Oktober 2015

Waktu :09.00 s/d 16.00 WIB

Tempat : lokasi wisata Pantai Air Manis

\section{Deskripsi Kegiatan:}

Kegiatan ini dilakukan dengan tujuan supaya informasi yang disampaikan dapat merata diterima oleh masyarakat. sistem ini dilakukan mengingat warga masyarakat yang sibuk dengan pekerjaan sehari-hari dan tidak dapat hadir dalam penyuluhan yang dilakukan di galeri pariwisata.

Pada pukul 09.00 WIB tim pengabdian masyarakat sudah sampai di lokasi pantai Air Manis. Pedagang yang berjualan belum banyak, satu persatu pedagang mulai menyiapkan warung mereka. Beberapa pedagang di pantai Air Manis berjualan makanan seperti indome, nasi goreng, dan makanan ringan. Pedagang juga menjual berbagai minuman. Pedagang pakaian merapikan dagangannya. Pagi ini tim pengabdian masyarakat melakukan penyuluhan kepada pedagang yang ada di pantai. Aktivitas ini dilakukan sampai pukul 16.00 WIB. Dalam waktu sehari ini kami berhasil memberikan penyuluhan sadar wisata dan sapta pesona di 10 warung yang ada di lokasi wisata.

Tahap 3 dan Tahap 4 tim melakukan pemantauan dan evaluasi terhadap perilaku masyarakat sekitar pantai Air Manis dalam melayani wisatawan. Sedikit banyaknya perilaku masyarakat telah mengalami perubahan dalam melayani wisatawan. Wlaupun dengan demikian belum dapat dikatakan dapat mengubah pola perilaku lama secara instan.

\section{Pencapaian Sasaran}

Sasaran kegiatan pelatihan dapat tercapai dengan melihat antusias dari peserta yang hadir dan juga memberikan pertanyaan dan tanggapan dalam diskusi. Materi yang diberikan selain dapat memberikan pengetahuan kepada mereka, juga membantu anggota masyarakat meningkatkan partisipasi mereka dalam pariwisata. Sasaran dan tujuan kegiatan cukup tercapai dengan adanya keinginan dari masyarakat untuk melakukan kelompok-kelompok Sadar wisata dan komunitas sesuai dengan pekerjaan seperti pedagang, tukang parkir, untuk memudahkan dalam pemetaan pariwisata. Dinas pariwisata juga mengharapkan adanya pendampingan secara terus menerus dalam pengembangan pariwisata pantai Air Manis oleh tim pengabdian masyarakat.

\section{Hasil Kegiatan}

Berdasarkan wawancara dan pengamatan langsung selama kegiatan berlangsung, kegiatan pengabdian masyarakat memberikan hasil sebagai berikut:

a. Meningkatnya pengetahuan dan pemahaman warga masyarakat Air Manis khususnya para pedagang sekitar pantai Air Manis mengenai pelayanan terhadap wisatawan.

b. Meningkatnya peran serta masyarakat dengan adanya upaya membentuk kelompok sadar wisata berdasarkan bidang-bidang pekerjaan.

c. Harapan masyarakat dan dinas pariwisata untuk dapat tim pengabdian melakukan pendampingan pariwisata pada periode berikutnya.

\section{Faktor Pendukung}

Faktor pendukung dalam kegiatan ini adalah kehadiran para peserta di lokasi kegiatan, serta adanya ruangan milik dinas pariwisata tempat mengumpulkan warga dan melaksanakan penyuluhan. Faktor pendukung lainnya yaitu kehadiran dari Dinas Pariwisata Kota Padang, pegawai pariwisata dan juga pihak kelurahan beserta tokoh masyarakat dalam acara ini. Dalam pelaksanaan kegiatan sempat 
listrik mati, namun cepat diatasi karena adanya generator listrik yang tersedia oleh dinas pariwisata di galeri.

Masyarakat pantai Air Manis sangat berharap pariwisata mereka dapat berkembang dan pengunjung banyak yang datang ke lokasi Wisata. Langkah untuk menghadirkan wisatawan yang banyak ke lokasi wisata Air Manis yaitu memberikan pelayanan yang baik pada wisatan dengan prinsip Sapta Pesona. Wisatawan yang puas dengan pariwisata Air Manis menjadi iklan yang manjur dalam pengembangan wisata, karena mereka akan memberitahukan kepada teman-teman lainnya, dan bahkan dengan adanya media sosial saat ini memudahkan dalam menyampaikan informasi kepada orang lain.

\section{Faktor Penghambat}

Faktor penghambat dalam kegiatan ini, pertama yaitu faktor waktu yaitu peserta yang sebagian besar pedagang yang konsumennya adalah wisatawan yang datang ke pantai Air Manis, yang banyak pada hari Sabtu dan Minggu. Oleh karena itu kegiatan dilaksanakan pada hari rabu. Kedua, keinginan masyarakat sangat besar untuk menjadi peserta, tetapi tentu tidak bisa menghadirkan semua pedagang. Oleh karena itu dilakukan secara jemput bola dengan mendatangi pedagang ke tempat berjualan dan memberikan penyuluhan mengenai sadar wisata di tempatnya berjualan tersebut.

\section{Kesimpulan}

Kegiatan pengabdian kepada masyarakat untuk meningkatkan sadar wisata masyarakat Air Manis dengan melakukan penyuluhan dapat terlaksana dengan baik, sehingga diharapkan dapat meningkatkan kepedulian masyarakat Air Manis terhadap sadar wisata tersebut. Minimal penyuluhan ini dapat memberikan pengetahuan kepada masyarakat Air Manis bagaimana berperan sebagai host dalam konteks Daerah Tujuan Wisata yang tentu saja menjadi tujuan dari wisatawan (guest/ tourist). Kesan yang baik yang diharapkan oleh wisatawan terhadap host dan lingkungan alam daerah tujuan wisata sangat diharapkan, baik oleh pengelola pariwisata - Dinas Pariwisata dan Agen Perjalanan yang berhubungan langsung dengan wisatawan. Kesan yang baik inilah yang akan meningkatkan pertumbuhan jumlah kedatangan wisatawan.

Oleh karena itu penyuluhan sadar wisata ini diharapkan dapat menjadi pemicu kepada masyarakat untuk lebih meningkatkan kepeduliannya terhadap pariwisata dan dengan demikian juga akan meningkatkan jumlah kunjungan wisatawan karena kepedulian masyarakat tersebut akan menciptakan kesan yang baik oleh wisatawan. Adanya kesan yang baik inilah yang akan meningkatkan jumlah kunjungan wisatawan ke Air Manis.

\section{Daftar Pustaka}

Darsoprajitn, Suwarno. (2002). Ekologi Pariwisata. Angkasa Offset. Jakarta

Fitriani, Erda \& Adri Febrianto. Stereotipe Masyarakat Lokal terhadap Perilaku Wisatawan, Laporan penelitian dana DIPA tahun 2014. UNP.Padang

http://ravelling.bisnis.com/read/20131001/224/166303/banyak-acara-skala-besar-kunjungan-turis-kesumbar-meningkat

Nugroho, Iwan. (2011). Ekowisata dan Pembangunan Berkelanjutan. Pustaka Pelajar Yogyakarta

Pergerakan arus kunjungan wisata ke Propinsi Sumatera Barat, data dari Dinas Kebudayaan \&

Pariwisata Sumbar, www.sumbarprov.go.id).

Picard, Michel. (2006). Bali: Pariwisata budaya dan Budaya Pariwisata. Gramedia. Jakarta.

Pitana, I Gde \& I Ketut Surya Diarta. (2009). Pengantar Ilmu Pariwisata. Andi Publishing. Yogjakarta.

Spilane, James. (1994). Pariwisata Indonesia: Siasat Ekonomi atau rekayasa Kebudayaan. Kanisius. Yogyakarta.

Yoeti, Oka A. (1996). Pengantar Ilmu Pariwisata. Angkasa. Bandung (1997). Perencanaan dan Pengembangan Pariwisata. Pradnya Paramita. Jakarta 